\title{
USULAN PERBAIKAN FORM APPRAISAL UNTUK PENILAIAN KINERJA KARYAWAN PT.XYZ
}

\author{
Anni Rohimah ${ }^{1}$, Zulfa Fitri Ikatrinasari ${ }^{2}$, \\ ${ }^{1}$ Magister Teknik Industri / Pasca Sarjana / Universitas Mercu Buana \\ ${ }^{1}$ Magister Teknik Industri / Pasca Sarjana / Universitas Mercu Buana
}

\begin{abstract}
A performance management system is a process of identifying, measuring and developing organizational performance, in which the performance and goals of each individual are linked to the organization's goals and mission. One part of performance management is performance measurement. Performance measurement is done by appraisal form. PT XYZ has used appraisal form to measure employee performance. Assessment is done once a year in December. In the implementation, there are difficulties faced by the appraiser, which are still the same assessment parameters for the operator and coordinator level, the overcrowding rating scale, the biased parameters, the complicated and too much form fields. After the analysis, it is proposed that there is a change to the appraisal form used which is simplifying the appraisal form and adding the leadership parameters for the coordinator level.
\end{abstract}

Keywords: performance, apparaisal, employee, form, assessment,

\begin{abstract}
ABSTRAK
Sistem manajemen kinerja adalah suatu proses berkelanjutan dalam mengidentifikasi, mengukur dan mengembangkan kinerja organisasi, dimana kinerja dan tujuan setiap individu terhubung dengan tujuan dan misi organisasi. Salah satu bagian dari manajemen kinerja adalah pengukuran kinerja. Pengukuran kinerja dilakukan dengan form appraisal.PT XYZ sudah menggunakan form appraisal untuk mengukur kinerja karayawan. Penilaian dilakukan setahun sekali di bulan Desember. Dalam pelaksanaanya, terdapat kesulitan yang dihadapi karyawan penilai, yaitu parameter penilaian masih sama untuk level operator dan coordinator, skala penilaian terlalu rapat, parameter yang bias, isian form rumit dan terlalu banyak. Setelah dilakukan analisa, diusulkan ada perubahan untuk form appraisal yang digunakan yaitu menyederhanakan form appraisal tanpa menyertakan keterangan parameter dan menambahkan parameter kepemimpinan untuk level coordinator.
\end{abstract}

Kata Kunci : kinerja, penilaian, karyawan, formulir, pengukuran

\section{PENDAHULUAN}

PT. XYZ adalah perusahaan yang didirikan pada tahun 1993. Proses produksi dan assembling yang dilakukan PT. XYZ ditunjang oleh mesin dan peralatan yang modern. Proses produksi juga didukung oleh Sumber Daya Manusia, mulai dari level operator, koordinator, foreman, supervisor, asisten manager, manager dan general manager. Untuk mendukung kinerja perusahaan secara global, salah satu kebijakan yang ditetapkan PT XYZ adalah Sumber Daya Manusia yang berkualitas.

PT. XYZ adalah perusahaan produsen peralatan rumah tangga. Perusahaan ini sudah menggunakan form Appraisal sebagai tools untuk pengukuran kinerja karyawan. Form Appraisal diisi di akhir tahun sebagai dasar untuk penilaian karyawan dan menentukan reward untuk karyawan. Hasil penilaian karyawan digunakan juga untuk proses promosi. 
Dari wawancara, diketahui ada beberapa masalah yang dihadapi oleh karyawan yang mengisi form appraisal tersebut, yaitu level supervisor, dan manager.

Berdasarkan uraian latar belakang masalah di atas, perumusan masalah yang menjadi objek kajian dalam penelitian ini adalah sebagai berikut:

1. Apa saja kendala yang dihadapi saat penggunaan Form Appraisal tersebut?

2. Apakah tindakan improvement yang diperlukan?

Agar penelitian lebih fokus dan relevan maka ada beberapa batasan yang ditetapkan, yaitu:

1. Penelitian hanya dilakukan di satu lokasi plant yaitu Tangerang,

2. Object Penelitian adalah form appraisal untuk level operator, dan coordinator

3. Wawancara hanya dilakukan kepada karyawan yang memberi penilaian di form appraisal, tidak mencakup wawancara terhadap karyawan dinilai.

Tujuan dalam penelitian ini adalah sebagai berikut :

1. Menemukan kendala yang dihadapi saat penggunaan Form Appraisal

2. Mengusulkan tindakan improvement untuk mengatasi kendala pengisian Form Appraisal

\section{TINJAUAN PUSTAKA}

\subsection{Sistem Manajemen Kinerja}

Sistem manajemen kinerja adalah suatu proses berkelanjutan dalam mengidentifikasi, mengukur dan mengembangkan kinerja organisasi, dimana kinerja dan tujuan setiap individu terhubung dengan tujuan dan misi organisasi (Aguinis,2008).

Salah satu bagian dari manajemen kinerja adalah pengukuran kinerja. Pengukuran kinerja dilakukan dengan form appraisal.

\subsection{Karakteristik Form Appraisal}

1. Sederhana, mudah dimengerti, mudah didokumentasikan, dan mudah diisi.

2. Relevan, informasi form terkait langsung dengan tugas dan tanggung jawab.

3. Jelas, form memiliki deskripsi yang jelas untuk setiap level kinerja.

4. Adaptif, dapat diaplikasikan untuk penggunaan di berbagai unit kerja.

5. Komprehensif, mencakup seluruh aspek kinerja untuk pekerjaan yang dinilai.

6. Kejelasan defenisi, kompetensi dan hasil yang diharapkan didefenisikan dengan jelas agar penilai konsisten dalam melakukan penilaian.

7. Komunikasi, komponen penilaian dikomunikasikan kepada semua orang yang terlibat dalam penilaian.

8. Orientasi waktu, form yang baik membantu membuat ekspektasi kinerja tidak hanya pada masa lalu (past) tapi juga masa depan (future).

\subsection{Komponen Appraisal Form}

Appraisal Form yang baik terdiri atas komponen berikut:

1. Informasi dasar pekerja: meliputi nama pekerjaan, unit kerja, jumlah pekerja, dan peringkat gaji atau klasifikasi gaji.

2. Akuntabilitas, sasaran dan standar kerja.

3. Kompetensi dan indikator.

4. Pencapaian dan kontribusi utama

5. Perkembangan pencapaian

6. Input stakeholder

7. Komentar pekerja

8. Tanda tangan

\section{HASIL, ANALISA DATA, DAN PEMBAHASAN}

Dari wawancara, diketahui bahwa permasalahan dalam pengisian form Apparaisal adalah:

\section{Parameter penilaian masih sama untuk level operator dan koordinator}


Untuk level Koordinator, belum ada parameter mengenai kepemimpinan, padahal koordinator adalah pemimpin bagi para operator

2. Skala penilaian terlalu rapat

Skala penilaian saat ini adalah :

-) Kurang Sekali

-) Kurang

-) Cukup

-) Baik

-) Baik Sekali

3. Parameter yang bias

Paramater penilaian memiliki definisi yang mirip sehingga menimbulkan bias, diantaranya:

-) Quality dan Quantity

Salah satu target penilaian yang bias adalah "banyaknya hasil kerja karyawan dibanding karyawan lainnya"

-) Quantity dan Kreatifitas

Salah satu target penilaian yang bias adalah "tingkat keterampilan yang dimiliki"

\section{Isian form rumit dan terlalu banyak}

Form tidak hanya berisi daftar parameter dan skala penilaian, tetapi berisi penjelasan masing-masing skala penilaian.

\section{KESIMPULAN}

Untuk mengatasi empat permasalahan utama dalam pengisian form Appraisal, diusulkan perbaikan form appraisal sebagai berikut :

1. Penambahan Parameter "Kepemimpinan" untuk level koordinator

2. Penyederhanaan Skala Form Appraisal, Menjadi :

-) Kurang

-) Cukup

-) Baik

3. Untuk mengurangi bias penialaian, maka cukup ada satu parameter penilaian yaitu "Keterampilan"

Form Appraisal hasil improvement yang diusulkan adalah sebagai berikut:

\begin{tabular}{|c|c|c|c|c|c|c|c|c|c|c|}
\hline \multirow{3}{*}{ No. } & \multirow{3}{*}{ Nama Karyawan } & \multicolumn{3}{|c|}{ Kedisiplinan } & \multicolumn{3}{|c|}{ Kerjasama dan Kepemimpinan } & \multicolumn{3}{|c|}{ Ketrampilan } \\
\hline & & Baik & Cukup & Kurang & Baik & Cukup & Kurang & Baik & Cukup & Kurang \\
\hline & & (3) & (2) & (1) & (3) & (2) & (1) & (3) & (2) & (1) \\
\hline & & & & & & & & & & \\
\hline & & & & & & & & & & \\
\hline & & & & & & & & & & \\
\hline & & & & & & & & & & \\
\hline & & & & & & & & & & \\
\hline & & & & & & & & & & \\
\hline & & & & & & & & & & \\
\hline & & & & & & & & & & \\
\hline & & & & & & & & & & \\
\hline & & & & & & & & & & \\
\hline & & & & & & & & & & \\
\hline & & & & & & & & & & \\
\hline
\end{tabular}

Gambar 1. Usulan Form Appraisal hasil improvement

\section{DAFTAR PUSTAKA}

Aguinis, H. 2008. Performance Management. 2nd ed.New York: Prentice Hall 